\title{
THE EFFECT OF CYTOCHROME C UPON THE METABOLISM OF RAT TISSUES
}

\author{
By WILLIAM C. STADIE AND JULIAN B. MARSH \\ (From the John Herr Musser Department of Research Medicine, University \\ of Pennsylvania, Philadelphia, Pa.)
}

(Received for publication February 4, 1947)

Recently, Proger and his co-workers have published papers dealing with the effects of parenteral injections of cytochrome $\mathrm{C}$ on conditions associated with tissue anoxia ( 1 to 8 ). They found, in man, that the changes in the visual acuity, electrocardiogram, and electroencephalogram associated with anoxia were partially or completely prevented by the antecedent intravenous injection of relatively small amounts of cytochrome $\mathrm{C}$.

These phenomena were explained by Proger by assuming that in anoxia essential oxidative processes were limited by the low concentration in the cells of cytochrome $C$ relative to cytochrome oxidase. By parenteral injection the concentration of cytochrome $\mathrm{C}$ within the cells was increased, the limitation of oxidative processes was removed, and tissue function restored toward normal.

Proger discussed further experiments bearing on the problem of the role of cytochrome $\mathrm{C}$ in tissue anoxia: (1) $\mathrm{He}$ reported (5) that the adenosine triphosphate (ATP) of heart and kidney of rats subjected to anoxia was markedly reduced. The antecedent parenteral injection of cytochrome $\mathrm{C}$ significantly prevented this reduction. It is well known that the organic phosphates, particularly ATP, play important roles in tissue metabolism. The regeneration of these energy rich phosphate bonds is dependent upon oxidative processes. Presumably, then, increase of cellular cytochrome $\mathrm{C}$ by injection removed the limiting factor of its naturally occurring low concentration, increased oxidative processes associated with the regeneration of ATP, and thus prevented the decrease otherwise accompanying anoxia. (2) $\mathrm{He}$ also found that cytochrome $\mathrm{C}$ together with hydroquinone (4) increased the oxygen uptake of homogenized tissues in vitro.

These 2 experiments were considered by Proger to support his concept of the role of parenterally administered cytochrome $\mathrm{C}$ in combating tissue anoxia. There are, however, theoretical difficulties in the acceptance of this explanation, viz.: (1) How can the large molecule of cytochrome $C$ (molecular weight approximately 13,000) enter into the interior of the cell in order to function? (2) Is the cytochrome $\mathrm{C}$ concentration of tissues so low that it is a limiting factor in metabolism under normal extraordinary physiological demands?

In this paper the interesting problem of the possible beneficial effect of parenteral injections of cytochrome $C$ in anoxic states was studied in 3 ways: (1) The adenosine triphosphate (ATP) concentration of kidney tissue in rats in the normal state, in anoxia, and in anoxia subsequent to cytochrome $\mathrm{C}$ administration was studied. (2) Experiments werre performed to determine the effect of cytochrome $\mathrm{C}$ on the oxygen uptake in vitro of diaphragms, liver and kidney slices from rats. (3) Using a recent value for the turnover number of cytochrome $\mathrm{C}$ together with cytochrome $\mathrm{C}$ concentrations of various tissues, the limiting values of oxygen uptake imposed by these 2 factors was calculated and compared with the physiological range of oxygen uptake of the respective tissues.

\section{METHODS}

The concentration of inorganic phosphate, ATP, and total phosphate in the acid-soluble fraction of the kidney was determined by the methods of Kaplan and Greenberg (9). One hundred-minute hydrolyzable phosphate was determined by hydrolysis in $1 \mathrm{~N}_{2} \mathrm{SO}_{\text {, at }} 100^{\circ} \mathrm{C}$. All phosphate determinations were by the method of Fiske and Subbarow (10), using a Klett-Summerson photoelectric photometer with a $6,600 \mathrm{~A}^{\circ}$ filter.

The rats were made anoxic for 5 minutes by means of a 3 per cent $O_{2}-97$ per cent $N_{2}$ gas mixture passed through a funnel held over the animal's head. Cytochrome $\mathrm{C}$ was injected intravenously 10 minutes prior to the anoxic period in the manner reported by Proger et al (5).

The kidney was frozen with liquid air as quickly as possible following decapitation of the rat. The frozen kidney was ground to a powder under liquid air in a mortar, and this powder was added to a tared centrifuge 
tube containing 7 per cent trichloroacetic acid, following the procedure of Kaplan and Greenberg (9).

The cytochrome $\mathrm{C}$ was prepared according to the technique of Keilin and Hartree (11). The concentration was determined spectrophotometrically, using the constant 26.1 at $\lambda 550 \mathrm{~m} \mu$ for a millimolar solution of cytochrome $C$, with a cuvette depth of $1 \mathrm{~cm}$. This concentration is referred to pure cytochrome $C$ with 0.43 per cent Fe (Mol. wt. $=13,000)$. In addition the biological activity of the preparation was demonstrated by its ability to increase the oxygen uptake of rat liver homogenates in the presence of $0.01 \mathrm{M}$ succinate. The increment was of the order of 1 mole of $\mathrm{O}_{2}$ per mole of cytochrome $\mathrm{C}$ per minute, which is comparable to that obtained by Schneider and Potter (13) with their preparations of cytochrome $\mathrm{C}$.

In the experiments dealing with tissue slice respiration, the organs were removed immediately following decapitation and slices $0.35 \mathrm{~mm}$. in thickness were cut. The slices were placed in Warburg vessels containing $2 \mathrm{ml}$. of a medium of the following composition: $\mathrm{Na}_{2} \mathrm{HPO}_{4}, 0.020 \mathrm{M}$; $\mathrm{NaH}_{2} \mathrm{PO}_{4}, 0.020 \mathrm{M} ; \mathrm{KCl}, 0.005 \mathrm{M} ; \mathrm{MgCl}_{2}, 0.002 \mathrm{M} ; \mathrm{CaCl}_{2}$, $0.001 \mathrm{M} ; \mathrm{NaCl}, 0.09 \mathrm{M}$; glucose, $0.011 \mathrm{M} ; \mathrm{pH}=6.7$. Where noted, the glucose was replaced by succinate.

\section{RESULTS}

The effect of cytochrome $C$ on the ATP content of kidneys from normal and anoxic rats

The results presented in Table I- show that the anoxia caused a 74 per cent decrease in the ATP content of the kidneys of the normal, non-injected rats. The 100 -minute minus the 7-minute easily hydrolyzable phosphate, representing mainly hexose diphosphate, was decreased 52 per cent. There was no significant change in the inorganic and total phosphate content.

The rats made anoxic following injection of cytochrome $\mathrm{C}$ showed a similar reduction in the ATP and hexose diphosphate content of the kidney. There is no statistically significant difference in the data of the untreated and treated rats.

\section{The effect of cytochrome $C$ upon oxygen uptake of tissues in vitro}

It is well known (e.g., Elliott [12]) that the addition of cytochrome $C$ (together with some reductant such as hydroquinone or ascorbic acid) to homogenized tissue in vitro increases the oxygen uptake. The currently accepted explanation is that the cytochrome oxidase is in excess compared to cytochrome $\mathrm{C}$. Hence in the homogenate, in which both cytochrome oxidase and cytochrome
TABLE I

Partition of the organic acid-soluble phosphates (mgm. P per 100 grams wet weight) of kidneys from normal rats, anoxic rats, and rats previously injected with $5 \mathrm{mgm}$. of cytochrome $C$

\begin{tabular}{|c|c|c|c|c|}
\hline Condition of rat & $\begin{array}{c}\text { Inorganic } \\
\text { phos- } \\
\text { phate }\end{array}$ & $\begin{array}{l}\text { 7-minute } \\
\text { hydro- } \\
\text { lyzable } \\
\text { phosphate } \\
\text { (ATP) }\end{array}$ & $\begin{array}{c}100 \text {-minute } \\
\text { minus } \\
7 \text {-minute } \\
\text { hydro- } \\
\text { lyzable } \\
\text { phosphate }\end{array}$ & $\begin{array}{c}\text { Total } \\
\text { phosphate }\end{array}$ \\
\hline Normal & $\begin{array}{l}\text { mgm. } P \\
41.9 \\
31.6 \\
32.9 \\
32.0 \\
24.0 \\
28.8\end{array}$ & $\begin{array}{c}m g m . P \\
12.4 \\
5.6 \\
11.3 \\
13.0 \\
6.2 \\
6.4\end{array}$ & $\begin{array}{l}\text { mgm. } P \\
10.8 \\
11.3 \\
7.3 \\
3.7 \\
8.0\end{array}$ & $\begin{array}{c}\text { mgsw. } P \\
89.4 \\
90.7 \\
114.0 \\
93.1 \\
78.0 \\
93.0\end{array}$ \\
\hline Anoxic & $\begin{array}{l}27.8 \\
31.8 \\
33.2 \\
37.6 \\
3.6 \\
24.1 \\
13.8\end{array}$ & $\begin{array}{l}8.0 \\
0.9 \\
0.0 \\
0.9 \\
0.9 \\
2.3 \\
3.5\end{array}$ & $\begin{array}{l}\mathbf{3 . 3} \\
\mathbf{8 . 6} \\
\mathbf{3 . 4} \\
3.8 \\
1.2 \\
\mathbf{3 . 9} \\
\mathbf{3 . 1}\end{array}$ & $\begin{array}{r}99.5 \\
92.0 \\
82.0 \\
129.0 \\
112.0 \\
95.0 \\
123.0\end{array}$ \\
\hline $\begin{array}{l}\text { Anoxic, previously in- } \\
\text { jected with } 5 \mathrm{mgm} \text {. of } \\
\text { cytochrome } C\end{array}$ & $\begin{array}{l}37.8 \\
37.9 \\
44.6 \\
28.2 \\
23.1 \\
23.6 \\
24.4\end{array}$ & $\begin{array}{l}2.6 \\
2.4 \\
0.0 \\
3.4 \\
1.4 \\
4.7 \\
2.6\end{array}$ & $\begin{array}{l}7.8 \\
4.9 \\
3.9 \\
5.6 \\
4.2 \\
4.5 \\
2.2\end{array}$ & $\begin{array}{r}85.1 \\
91.5 \\
90.0 \\
118.0 \\
94.5 \\
112.0 \\
106.5 \\
\end{array}$ \\
\hline $\begin{array}{l}\text { Normal, mean } \pm \text { S.E. } \\
\text { Anoxic, mean } \pm S . \text {. } \\
\text { Anoxic, previousiy in } \\
\text { jected with cytochrome } \\
\text { C, mean } \pm \text { S.E. }\end{array}$ & $\begin{array}{l}31.9 \pm 2.5 \\
28.8 \pm 2.9 \\
31.4 \pm 3.2\end{array} \mid$ & $\begin{array}{l}9.2 \pm 1.4 \\
2.4 \pm 1.0 \\
2.4 \pm 0.6\end{array}$ & $\begin{array}{l}8.2 \pm 1.4 \\
3.9 \pm 0.6 \\
4.7 \pm 0.5\end{array}$ & $\begin{array}{r}93.0 \pm 4.8 \\
104.6 \pm 6.5 \\
99.7 \pm 4.7\end{array}$ \\
\hline
\end{tabular}

C are free, the further addition of cytochrome C saturates the cytochrome oxidase to a greater extent and oxygen uptake is enhanced. Proger (4) repeated experiments of this kind with homogenates and used them to support his general concept of the effect of cytochrome $\mathrm{C}$ on anoxia in the intact animal. It seems to the authors of this paper that such a phenomenon in homogenates has little or no meaning with respect to the problem at hand unless it can be shown that parenterally administered cytochrome $\mathrm{C}$ enters the intact cell. Elliott (12) was unable to find any influence of cytochrome $\mathrm{C}$ upon the $\mathrm{O}_{2}$ uptake in vitro of intact tissue and concluded that cytochrome $\mathrm{C}$ does not penetrate into intact cells.

To test whether the addition of cytochrome $\mathrm{C}$ to the medium would have any effect upon the oxygen uptake, we used relatively untraumatized tissue preparations such as kidney or liver slices, or whole rat diaphragms rather than homogenates. We found, in the presence of glucose or succinate, that cytochrome $C$ has no significant effect. The evidence is presented in Table II. 
TABLE II

The effect of cytochrome $C$ upon the oxygen uptake in vitro of diaphragms, kidney and liver slices from rats

\begin{tabular}{|c|c|c|c|c|}
\hline $\begin{array}{c}\text { Expt. } \\
\text { No. }\end{array}$ & $\begin{array}{c}\text { Tissue } \\
\text { preparation }\end{array}$ & $\begin{array}{l}\text { Medium } \\
\text { employed }\end{array}$ & $\begin{array}{c}\text { Oxygen } \\
\text { uptake, } \\
\text { no cyto- } \\
\text { chrome C }\end{array}$ & $\begin{array}{c}\text { Change in } \\
\text { oxygen uptake } \\
\text { in presence of } \\
\text { cytochrome C }\end{array}$ \\
\hline \multirow[t]{2}{*}{$\begin{array}{l}1 \\
2 \\
3 \\
4 \\
5 \\
6 \\
7 \\
8 \\
9\end{array}$} & \multirow[t]{2}{*}{ Diaphragm } & \multirow[t]{2}{*}{ Medium I* } & \begin{tabular}{|c|}
$\mu M O_{2}$ per \\
gram wet \\
weight per howr \\
85.7 \\
100.0 \\
75.4 \\
70.6 \\
71.4 \\
77.8 \\
82.4 \\
59.4 \\
58.6
\end{tabular} & $\begin{array}{r}\text { per cent } \\
11 \\
-14 \\
8 \\
15 \\
5 \\
-5 \\
-3 \\
0 \\
-2\end{array}$ \\
\hline & & & Mean & +1.7 \\
\hline \multirow[t]{2}{*}{$\begin{array}{l}10 \\
11\end{array}$} & \multirow[t]{2}{*}{ Kidney slices } & & $\begin{array}{l}158.5 \\
147.6\end{array}$ & $\begin{array}{r}-13 \\
-7\end{array}$ \\
\hline & & & Mean & -10.0 \\
\hline \multirow[t]{2}{*}{$\begin{array}{r}12 \\
13 \\
-14\end{array}$} & \multirow[t]{2}{*}{ Liver slices } & & $\begin{array}{l}65.6 \\
69.1 \\
87.8\end{array}$ & $\begin{array}{r}6 \\
-2 \\
-16\end{array}$ \\
\hline & & & Mean & -4.0 \\
\hline \multirow[t]{2}{*}{$\begin{array}{l}15 \\
16 \\
17 \\
18 \\
19\end{array}$} & \multirow[t]{2}{*}{ Diaphragm } & \multirow[t]{2}{*}{ Medium $\mathrm{II}^{*}$} & $\begin{array}{l}58.3 \\
79.3 \\
79.5 \\
68.1 \\
66.0\end{array}$ & $\begin{array}{r}8 \\
-10 \\
-13 \\
0 \\
11\end{array}$ \\
\hline & & & Mean & -4.0 \\
\hline
\end{tabular}

* Medium I contained glucose, $0.011 \mathrm{M} ; \mathrm{Na}_{2} \mathrm{HPO}_{4}$ $0.02 \mathrm{M} ; \mathrm{NaH}_{2} \mathrm{PO}_{4}, 0.02 \mathrm{M} ; \mathrm{KCl}, 0.005 \mathrm{M} ; \mathrm{MgCl}_{2}, 0.002 \mathrm{M}$; $\mathrm{CaCl}_{2}, 0.001 \mathrm{M}$; $\mathrm{NaCl}, 0.09 \mathrm{M}$. $\mathrm{pH}=6.7$. Medium II contained sodium succinate, $0.01 \mathrm{M}$ in place of the glucose in Medium I. Total vol. $2.5 \mathrm{ml}$. Cytochrome C $1.7 \mathrm{mgm}$. $t=38^{\circ} \mathrm{C}$.

The limiting cellular oxygen uptake imposed by cytochrome $C$ content

Proger (8) emphasized that the concentration of cytochrome $\mathrm{C}$ in tissues is below that required for maximum activation of cytochrome oxidase with which it is coupled in metabolic reactions. This, however, does not indicate that cytochrome $\mathrm{C}$ is necessarily a limiting factor in cellular oxygen consumption. From the data of Rosenthal and Drabkin (14) the turnover number of cytochrome $C$ expressed in terms of oxygen uptake is $2.3 \times$ $10^{7} \mu \mathrm{M}$ of $\mathrm{O}_{2}$ per gram (dry weight) per hour. On the basis of this figure we have calculated the values shown in Table III. These calculations indicate that the cytochrome $\mathrm{C}$ concentration of various rat organs is considerably beyond that required for the estimated physiological demand.
TABLE In

The calculated maximum oxygen uptake of various tissues calculated from the turnover number and tissue concentrations of cytochrome $C$ compared to physiological ranges of oxygen uptake

\begin{tabular}{|c|c|c|c|}
\hline Organ & Cytochrome C & $\begin{array}{c}\text { Calculated } \\
\text { oxygen uptake }\end{array}$ & $\begin{array}{l}\text { Approximate } \\
\text { physiological } \\
\text { range of } \\
\text { oxygen uptake }\end{array}$ \\
\hline & $\begin{array}{l}\text { per cent of } \\
\text { dry weight }\end{array}$ & $Q_{2}$ & QO2 \\
\hline $\begin{array}{l}\text { Kidney cortex } \\
\text { Liver } \\
\text { Brain cortex } \\
\text { Striated muscle } \\
\text { Heart }\end{array}$ & $\begin{array}{l}0.14 \\
0.06 \\
0.04 \\
0.05 \\
0.22\end{array}$ & $\begin{array}{r}720 \\
309 \\
206 \\
257 \\
1133\end{array}$ & $\begin{array}{c}10-50 \\
10-30 \\
10-40 \\
5-110 \\
3-60\end{array}$ \\
\hline
\end{tabular}

* From data from rats by Rosenthal and Drabkin (15). Expressed in terms of oxygen uptake the turnover number of cytochrome $\mathrm{C}$ used was $2.3 \times 10^{7} \mu \mathrm{M}$ of $\mathrm{O}_{2}$ per gram dry weight per hour. The calculation of the $Q_{2}$ is: $2.3 \times 10^{7} \times 22.4 \times 10^{-3} \times P \times 10^{-2}$ where $P$ is the per cent (dry weight) of cytochrome $C$ in the respective tissue. $Q_{\mathrm{O}_{2}}=\mathrm{cu}$. mm. O per mgm. dry weight per hour.

In the brain, for example, there appears to be a 5-fold reserve factor, and in striated muscle, the factor is 2 even under the demands of excessive muscular work. In the heart the factor of safety appears to be still greater, viz. 20. It is difficult, therefore, to understand, on the basis of the current concept of the function of cytochrome $\mathrm{C}$ in tissue oxidations, how the parenteral addition of a relatively small amount of cytochrome $C$, even if it could enter the cell, can affect oxidative cellular metabolism.

\section{SUMMARY}

1. The decreased adenosine triphosphate (ATP) content of anoxic rat kidney reported by Proger et al (5) has been confirmed. The prevention of the lowered ATP content of anoxic kidney by the antecedent intravenous administration of cytochrome $\mathrm{C}$, reported by these authors, has not been observed in the present experiments.

2. No alteration in the oxygen consumption of rat diaphragm and rat liver and kidney slices was observed following the addition of cytochrome $\mathrm{C}$ to the medium in vitro either with glucose or succinate as substrates.

3. Using the turnover number of cytochrome $\mathrm{C}$ and known values of tissue cytochrome $C$, the maximum oxygen uptake of various tissues was calculated. Comparison of these calculated values with the range of oxygen requirements lends no support to the concept that the cytochrome $\mathrm{C}$ con- 
tent of tissues is a limiting factor in cellular oxidations within physiological ranges.

We are indebted to Dr. David L. Drabkin of the Department of Physiological Chemistry for the spectrophotometric standardization of the cytochrome $\mathrm{C}$ solutions.

\section{BIBLIOGRAPHY}

1. Proger, S., Aisner, M., and Squires, R. B., The prevention of electrocardiographic evidences of myocardial anoxemia by chemical means. J. Clin. Invest., 1942, 21, 630.

2. Proger, S., The use of respiratory catalysts, particularly succinic acid in tissue anoxia. Bull. New England M. Center, 1943, 5, 80.

3. Proger, S., Dekaneas, D., and Schmidt, G., The increase of cytochrome $C$ content of organs following its parenteral injection. J. Clin. Invest., 1944, 23, 949.

4. Proger, S., Dekaneas, D., and Schmidt, G., Some observations on the effect of injected cytochrome C in animals. J. Clin. Invest., 1945, 24, 864.

5. Proger, S., Dekaneas, D., and Schmidt, G., The effects of anoxia and of injected cytochrome $C$ on the content of easily hydrolyzable phosphorus in rat organs. J. Biol. Chem., 1945, 160, 233.

6. Proger, S., and Dekaneas, D., The clinical use of cytochrome $\mathrm{C}$ in patients with intermittent claudication. Bull. New England M. Center, 1946, 8, 145.
7. Proger, S., and Dekaneas, D., Some further observations on the parenteral use of cytochrome $C$ with special reference to cerebral anoxia and shock. Bull. New England M. Center, 1945, 7, 149.

8. Proger, S., and Dekaneas, D., The use of cytochrome $\mathrm{C}$ in combating tissue anoxia. Science, 1946, 104, 389.

9. Kaplan, N. O., and Greenberg, D. M., Studies with radioactive phosphorus of the changes in the acidsoluble phosphates in the liver coincident to alterations in carbohydrate metabolism. I. Separation and nature of the organic acid-soluble phosphates of liver. J. Biol. Chem., 1944, 156, 511.

10. Fiske, C. H., and Subbarow, Y., The colorimetric determination of phosphorus. J. Biol. Chem., 1925, 66, 375.

11. Keilin, D., and Hartree, C. F., Proc. Roy. Soc. London, Series B, 1937, 122, 298.

12. Elliott, K. A. C., and Greig, M. E., The distribution of the succinic oxidase system in animal tissues. Biochem J., 1938, 32, 1407.

13. Schneider, W. C., and Potter, V. R., The assay of animal tissues for respiratory enzymes. II. Succinic dehydrogenase and cytochrome oxidase. J. Biol. Chem., 1943, 149, 217.

14. Rosenthal, O., and Drabkin, D. L., Cytochrome C, cytochrome oxidase and body size. Fed. Proc., 1943, 2, 69.

15. Rosenthal, O., and Drabkin, D. L., The cytochrome C content of normal and neoplastic mammalian epithelium, and its correlation with body mass. J. Biol. Chem., 1943, 150, 131. 